\title{
F. Paulin S. J., Idoménée, tragédie (1700)
}

\section{Monica Pavesio}

\section{(2) OpenEdition}

\section{Journals}

\section{Edizione digitale}

URL: http://journals.openedition.org/studifrancesi/7551

DOI: 10.4000/studifrancesi.7551

ISSN: 2427-5856

\section{Editore}

Rosenberg \& Sellier

\section{Edizione cartacea}

Data di pubblicazione: 1 décembre 2009

Paginazione: 618-619

ISSN: 0039-2944

\section{Notizia bibliografica digitale}

Monica Pavesio, «F. Paulin S. J., Idoménée, tragédie (1700)», Studi Francesi [Online], 159 (LIII | III)| 2009, online dal 30 novembre 2015, consultato il 09 janvier 2021. URL: http://journals.openedition.org/ studifrancesi/7551; DOI: https://doi.org/10.4000/studifrancesi.7551

\section{Questo documento è stato generato automaticamente il 9 janvier 2021}

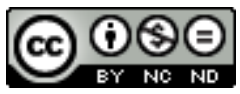

Studi Francesi è distribuita con Licenza Creative Commons Attribuzione - Non commerciale - Non opere derivate 4.0 Internazionale. 


\title{
F. Paulin S. J., Idoménée, tragédie (1700)
}

\author{
Monica Pavesio
}

\section{NOTIZIA}

F. PAULIN S. J., Idoménée, tragédie (1700), texte établi et présenté par J.-Ph, GROSPERRIN, Toulouse, Société de Littérature Classiques, 2008, pp. 143.

1 J. Ph Grosperrin presenta una riedizione accurata di un'interessanate tragedia gesuitica dedicata ad Idomeneo. Si tratta della prima tragedia francese sullo sfortunato re di Creta, che precede di cinque anni la tragedia di Crébillon père, considerato fino ad oggi il primo autore francese ad aver portato sulle scene la vicenda tragica di Idomeneo, nel 1705. Fu invece nel teatro dei collegi gesuitici che il re e suo figlio fecero il loro ritorno sulle scene francesi, in questa tragedia composta dal professore di retorica François Paulin, rappresentata presso il collegio della Trinità di Lione nel 1700, e ritrovata presso la biblioteca municipale di Grenoble in una collezione di manoscritti.

Oltre ad essere la più antica opera drammatica sul mito di Idomeneo in Francia, la tragedia si inserisce nel quadro particolare delle cerimonie del collegio lionese, nell'eredità della tragedia raciniana e nella meditazione cristiana su un mito che solleva ed ha sollevato gravi perplessità morali e religiose. Si tratta dunque di una preziosa testimonianza della drammaturgia e dello spirito del teatro gesuitico di fine Seicento, di una nuova interpretazione di questa favola del sacrificio che raggiungerà alla fine del secolo successivo con l'Idomeneo di Mozart, il massimo splendore teatrale.

Un'interessante introduzione sulla tragedia inserita nel suo ambito di appartenenza, il teatro gesuitico dei collegi, una ricca bibliografia ed una serie di appendici sulle fonti classiche e contemporanee, sulla presenza del mito nel teatro francese fra il 1690 ed il 1792 (con le presentazioni delle tragedie gesuitiche e alcuni estratti della tragedia di Crébillon père), sulla presenza del sacrificio del figlio nel teatro dei collegi e sulle 
rappresentazioni del teatro della Trinità di Lione dal 1658 al 1751, completano l'edizione critica, condotta con metodi conservativi. 